Mesopotamia J. of Agric.

Vol. (42) NO. (1) 2014
ISSN: 2224-9796 (Online)

ISSN: $1815-316 \times$ (Print)

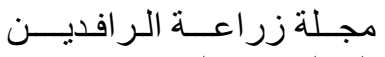

المجلد(42) العدد(1) 2014 ألمرافن

\title{
EFFECT OF DIFFERENT LEVELS OF PHOSPHORUS FERTILIZER ON11 HEAVY METALS CONCENTRATION IN DIFFERENT PARTS OF WHEAT PLANT
}

Ismaeel T. Ahmad

Akram O. Esmail

Soil and Water Dept. College of Agric. - Salahaddin University, Arbil/ Iraq ismaeelshexbzeny@yahoo.com

\begin{abstract}
A biological experiment was conducted at 20/1/2011 to $2 / 6 / 2011$ in pots in the experimental farm of college of Agriculture, $3.5 \mathrm{~km}$ south of Arbil governorate, $36^{\circ} 07 \mathrm{~N}, 44^{\circ} 01 \mathrm{E}, 0411359,03997002$ UTM. $411 \mathrm{~m}$ above the sea level, during growing season 2011-2012 in order to determine the effect of different levels of phosphorus $\left(0,10,20,30\right.$, and $40 \mathrm{mgkg}^{-1}$ on heavy metals concentrations and uptake for different parts roots, shoots and grains of wheat plant Triticum durum L. cv.Summit. Soil samples were collected under the polluted location in the landfills were located between Bnaslawa district and Daratoo county, triple super phosphate fertilizer applied to soils to know the effect of phosphorus absorption and distribution of heavy metals in the different parts of wheat plant by using factorial Complete Randomize Design (CRD) with four replicates. The present investigation started at 24/1/2011 and plants were harvested at 2/6/2011. The increase of applied $\mathrm{P}$ caused a significant increase $(\mathrm{p} \leq 0.05)$ of the dry matter weight of different parts of plant (roots, shoots and grains) and a significant decrease of heavy metal concentration. A negative correlation coefficient between $\mathrm{P}$ and $\mathrm{Fe}, \mathrm{Ni}, \mathrm{Cd}$ and $\mathrm{Pb}$ concentrations in roots were $(0.98,0.94,0.95$ and 0.99 and in shoots part $0.69,0.93$, 0.89 , and 0.99 and in grains part $0.89,0.90,0.97$, and 0.96) respectively.
\end{abstract}

Key words: Phosphorus, heavy metals, uptake.

Received: 15/ 5 / 2012 Accepted: 15/10/ 2012

\section{INTRODUCTION}

The application of different $\mathrm{P}$ amendments causes heavy metals in soils to shift from forms with high availability to the most strongly bound metals fractions (Miretzky and Fernandez-Cirelli, 2010). Heavy metals that can accumulate to high levels in specific crops. Heavy metals have been linked to negative health effects, so it is desirable to reduce the heavy metal concentrations of crops entering the human diet. Heavy metals concentration in crops is influenced by a wide range of factors, including crop genetics, soil characteristics such as texture, $\mathrm{pH}$ and salinity, weather, crop sequence, crop management practices and soil heavy metal concentration(Grant et al. 1999). Heavy metals are present at varying concentrations as a contaminant in phosphate (P) fertilizers (Taylor 1997;Grant et al. 2002; Grant and Sheppard 2008) and repeated applications of $\mathrm{P}$ fertilizers may decrease heavy metals content of soils, potentially increasing trace metals content of crops across a range of soils and environments. Heavy metal reaches the soil environment through pedogenic, related to the origin and nature of the parent material, and anthropogenic processes. Anthropogenic activities primarily associated with industrial processes, manufacturing and the disposal of domestic and industrial waste materials are the

Cited from $\mathrm{PhD}$ thesis of first researcher. 
Mesopotamia J. of Agric.

Vol. (42) NO. (1) 2014
ISSN: 2224-9796 (Online)

ISSN: $1815-316 \times$ (Print)

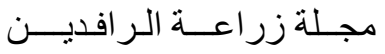

المجلد(42) العدد(1) 2014 ألمرافن

major source of lead contamination of soils (Adriano, 2001). The normal ranges of heavy metals $(\mathrm{Fe}, \mathrm{Ni}, \mathrm{Cd}$, and $\mathrm{Pb}$ in soil were 500-5000, 5-500, 0.01-2 and 2-300 $\left.\mathrm{mgkg}^{-1}\right)$ and in plant were (1.1-160, 0.1-5, 0.05-0.2 and 5-10 $\left.\mathrm{mgkg}^{-1}\right)$ respectively according to (Kabata-Pendias and Pendias, 2001). This study was conducted to determine the long-term influence of Phosphorus applied (triple super phosphate) on heavy metals $(\mathrm{Fe}, \mathrm{Ni}, \mathrm{Cd}$ and $\mathrm{Pb}$ ) concentration of different parts of durum wheat (roots, shoots and grains).

\section{MATERIALS AND METHODS}

Soils were collected from landfills located between Bnaslawa district and Daratoo County; the GPS reading of the studied locations were recorded. The soils were taken from the soil surface (0-30) $\mathrm{cm}$ depth Table (1).

Table (1). Some selected chemical and physical properties of the studied soils.

\begin{tabular}{|c|c|c|c|c|c|c|c|c|c|c|c|c|c|}
\hline \multirow{2}{*}{$\mathrm{pH}$} & $\mathrm{EC}$ & $\mathrm{M}$ & $\mathrm{O} . \mathrm{M}$ & $\mathrm{T} . \mathrm{CaCO}_{3}$ & $\mathrm{Fe}$ & $\mathrm{Ni}$ & $\mathrm{Cd}$ & $\mathrm{Pb}$ & \multicolumn{5}{|c|}{ Particle Size Distribution } \\
$\mathrm{gkg}^{-1}$
\end{tabular}

* (M \%) Moisture percentage, (O.M) Organic matter.

The biological experiment included packing the pots each pot $(22 \mathrm{~cm}$ height, $22 \mathrm{~cm}$ top diameter and $16 \mathrm{~cm}$ bottom diameter) packed with same weight $(6 \mathrm{~kg})$ of dry soil after passing through (4) mm sieve. On 24/1/2011.Thirteen seeds of wheat Tritium durum L. cv. Summit were planted in each pot at (5) $\mathrm{cm}$ depth, then thinned to (8) seedling / pot after two weeks of germination. The pot experiment included five levels of phosphorus $(0,10,20,30$ and $40 \mathrm{mg} \mathrm{P} \mathrm{kg}$ soil) using (Triple Super Phosphate \% $46 \mathrm{P})$ which equivalent to $(0.00,21.73,43.47,67.39$ and $86.95 \mathrm{mg}$ TSP $\mathrm{kg}^{-1}$ soil) by applying factorial CRD with four replicates, a fixed amount of nitrogen (22.5 mg N kg${ }^{-1}$ soil) equivalent to $90 \mathrm{~kg} \mathrm{~N} \mathrm{ha}^{-1}$ was added to all the pots. The supplemental irrigation was done by depending on weighing method whenever needed. The plants were harvested on $2 / 6 / 2011$. Plant roots, shoots and grains were separated, then root of plants were washed with distilled water to clean the soils from the samples and then oven dried at $65{ }^{\circ} \mathrm{C}$ for 48 hours. After weighting and grinding with stainless steel mill, the samples were stored for further analysis (Mekeague, 1978).The phosphorus was determined by using ammonium molybdate with $\mathrm{SnCl}_{2}$ according to Allen et al., (1974). $0.3 \mathrm{~g}$ of powdered dried samples (roots, shoots and grains) digested separately by mixed acid digestion $\left(5 \mathrm{ml}\right.$ of $\mathrm{HNO}_{3}, 1 \mathrm{ml}$

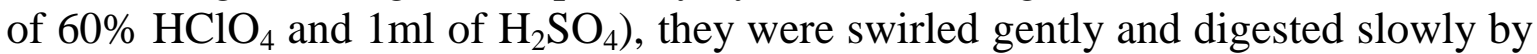
gradual temperature increase, after appearance of white fumes, the colorless digested samples were diluted and filtered through filter paper (No.42) and completed to $50 \mathrm{ml}$; the blank was carried out in the same way but without sample, the heavy metal concentrations of $\mathrm{Fe}, \mathrm{Ni}, \mathrm{Cd}$ and $\mathrm{Pb}$ were determined by using Atomic Absorption Spectrophotometer (AAS) Alpha-4-according to (Hseu et al., 2002), after preparation of appropriate calibration standards. All the samples were digested and analyzed in replicate. The statistical analysis was carried out using Statistical Analysis System (SAS Version 9.1).Data analysis were made using oneway analysis of variance (ANOVA).The comparison among groups was done using LSD test $(\mathrm{p} \leq 0.05)$ was considered as statistical significant (Anonymous, 2005). 
Mesopotamia J. of Agric.

Vol. (42) NO. (1) 2014
ISSN: 2224-9796 (Online)

ISSN: $1815-316 \times$ (Print)

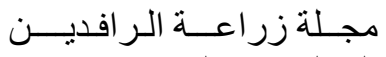

المجلد(42) العدد(1) 2014 ألمرافن

\section{RESULTS AND DISCUSSION}

1 - Phosphorus and Wheat growth parameters:-Growth parameters (root dry weight and shoot dry matter) and grain yield Tables (2, 3 and 4). Were influenced by soil $\mathrm{P}$ fertilization rate .Soil $\mathrm{P}$ application had a significant increase on both root and shoot dry matter production and on yield of wheat plants. This increase is attributed to sufficient $\mathrm{P}$ supply where an essential nutrient for plant growth due to its role in plant biological processes such as the formation and division of living cells in the transfer of genetic materials, energy storage and transfer like ADP and ATP, photosynthesis respiration, protein and nucleic acid synthesis, and ion transport across cell membranes (Havlin et al., 2007 and Fageria, 2009). Further more, the increase in dry matter weight may due to the role of $\mathrm{p}$ in chlorophyll formations, physiological processes and nutrient balance in plants .These results agree with those reported by (Hassan et al.1975; Russel, 2001; and Stewart et al. 2003).

2- Phosphorus and heavy metals uptake and Interaction: the $P$ treatment used in this study affected growth of wheat plants Tables (2, 3 and 4) whenever growth accumulation of dry matter or grain yield is altered the concentration and the uptake of plant nutrients is affected (Mengel and Kirkby, 2001).As expected, P supply increased $\mathrm{P}$ concentration and content in roots, shoots, and grains of wheat plants. Root - $\mathrm{P}$ concentrations were $11.89,4.60,5.40$ and $1.89 \%$ higher (Table 2), shoot-P concentrations were $8.85,6.25,2.86$ and $0.00 \%$ higher (Table 3), and grain-P concentration were $22.59,3.76,1.25$ and $0.41 \%$ higher (Table 4 ) in the $\mathrm{P}_{40,30,20,10}$ treatments respectively compared to $\mathrm{P}_{0.0}$ treatments with $\mathrm{P}$ contents in roots, shoots and grains. The same patterns were found when the contents increased with increasing the amount of $\mathrm{P}$ applied Tables (2, 3 and 4). The concentration and content of $\mathrm{P}$ in roots, shoots and grains of wheat plants seemed to reflect total supply of phosphorus more than any other factor. Similar results were stated by (Zhu et al., 2002) who found that with high $\mathrm{P}$ availability in soil solution barley plant biomass increased and concentrations of $\mathrm{P}$ were high.

Table (2): Effect of different levels of phosphorus on heavy metals concentration (mg. $\left.\mathrm{kg}^{-1}\right)$ in root parts and the heavy metals uptake $\left(\mu \mathrm{g}\right.$. pot $\left.^{-1}\right)$ by Wheat plant.

\begin{tabular}{|c|c|c|c|c|c|c|c|c|c|c|c|c|}
\hline \multirow[t]{2}{*}{$\begin{array}{l}\text { Part } \\
\text { of } \\
\text { plant }\end{array}$} & \multirow[t]{2}{*}{$\underset{\mathbf{k g}^{-1}}{\operatorname{mg}} \mathbf{P}$} & $\mathrm{Fe}$ & $\mathrm{Ni}$ & Cd & $\mathbf{P b}$ & \multirow{2}{*}{$\begin{array}{l}\mathrm{P} \\
\%\end{array}$} & \multirow{2}{*}{$\begin{array}{c}\begin{array}{c}\text { Dry } \\
\text { Matter } \\
\text { Weight }\end{array} \\
\text { g.pot }^{-1}\end{array}$} & $\mathrm{Fe}$ & $\mathrm{Ni}$ & Cd & $\mathbf{P b}$ & $\mathbf{P}$ \\
\hline & & \multicolumn{4}{|c|}{ Conc. (mg.kg-1) } & & & \multicolumn{5}{|c|}{ Uptake $\left(\mu \mathrm{g} \cdot\right.$ pot $\left.^{-1}\right)$} \\
\hline \multirow{6}{*}{ Root } & 0 & 75.00 & 0.180 & 0.020 & 3.31 & 0.326 & 5.96 & 447.00 & 1.073 & 0.119 & 19.727 & 1.943 \\
\hline & 10 & 74.70 & 0.179 & 0.016 & 2.94 & 0.353 & 6.40 & 478.08 & 1.145 & 0.102 & 18.816 & 2.259 \\
\hline & 20 & 74.00 & 0.168 & 0.007 & 2.23 & 0.350 & 7.10 & 525.40 & 1.193 & 0.049 & 15.833 & 2.485 \\
\hline & 30 & 69.83 & 0.162 & 0.006 & 1.47 & 0.363 & 7.30 & 509.76 & 1.182 & 0.044 & 10.73 & 2.650 \\
\hline & 40 & 66.62 & 0.159 & 0.003 & 0.82 & 0.370 & 7.32 & 487.66 & 1.163 & 0.022 & 6.002 & 2.708 \\
\hline & LSD $_{.05}$ & 10.18 & 0.005 & 0.0239 & 0.305 & 0.010 & 1.005 & 78.79 & 0.172 & 0.0154 & 3.404 & 0.335 \\
\hline
\end{tabular}

3- Phosphorus supply generally decreased, $\mathrm{Fe}, \mathrm{Ni}, \mathrm{Cd}$ and $\mathrm{Pb}$ concentrations and contents in roots, shoots and grain of wheat plant. Phosphorus supply significantly decreased Fe concentration. Root Fe concentrations were 0.4, 1.33, 6.89 and $11.17 \%$ 
Mesopotamia J. of Agric. Vol. (42) NO. (1) 2014
ISSN: 2224-9796 (Online)

ISSN: $1815-316 \times$ (Print)

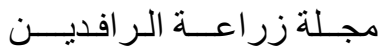

المجلد(42) العدد(1) 2014

lower Table (2), shoot Fe only 30, $40 \mathrm{mg} \mathrm{P} \mathrm{kg}^{-1}$ caused decrease of Fe concentration, while the application of 10 and $20 \mathrm{mg} \mathrm{P} \mathrm{kg}^{-1}$ caused increase in Fe concentration, this may be due to higher concentration of $\mathrm{Fe}$ in root increase application of 10 and $20 \mathrm{mg}$ $\mathrm{P} \mathrm{kg}^{-1}$ were 0.72 and $3.72 \%$ lower Table (3), and grain Fe concentrations were 0.98 , 5.90, 5.95 and $6.62 \%$ lower Table (4) in the $\mathrm{P}_{10,20,30,40}$ treatments as compared to $\mathrm{P}_{0.0}$ treatments. Our results showed that $\mathrm{P}$ interfered with $\mathrm{Fe}$ uptake and translocation (clearly when $\mathrm{P}$ concentration supply was high). The possible mechanism for this antagonism could be the reaction between $\mathrm{P}$ and $\mathrm{Fe}$ in soil and $\mathrm{Fe}$ precipitation as insoluble iron phosphate occurred. Iron - phosphate interactions commonly occur in both plant metabolism and soil media. The affinity between $\mathrm{Fe}$ and phosphorus ions is known to be great, and therefore the precipitation of $\mathrm{FePO}_{4} \cdot 2 \mathrm{H}_{2} \mathrm{O}$ can easily occur under favorable conditions (Kabata-Pendias and Pendias, 2001).

The application of $\mathrm{P}$ reduced the Ni concentration in roots, shoots and grains of wheat plants Tables (2, 3and 4). The concentrations of these heavy metals were higher at 0.0 level of $\mathrm{P}$ and decreased gradually with increasing the amount of $\mathrm{P}$ applied to the soil. Root $\mathrm{Ni}$ concentrations were $0.56,6.67,10.00$ and $11.67 \%$ lower, shoot $\mathrm{Ni}$ concentration were 11.53,19.23,19.23 and $30.77 \%$ lower and grain Ni concentrations were $0.0,0.28,0.56$ and $50.56 \%$ lower in the $\mathrm{P}_{10,20,30,40}$ treatments compared to $\mathrm{P}_{0.0}$ treatments. This may be due to the soil treatments such as addition of lime, phosphorus, organic matter, is known to decrease Ni availability to plants (Chaney et al., 1984). The concentration of $\mathrm{Cd}$ in root, shoot and grain was higher at zero (0) level of $\mathrm{P}$ applied to soil and the magnitude of reduction in Cd concentration with the application of $\mathrm{P}$ to soil in roots, shoots and grains of wheat plants were 20.0, 65.0, 70.0 and $85.0 \%$ (in roots) 80.0, 84.0, 89.0 and $90.0 \%$ (in shoots) and 75.0, 50.0, 75.0 and 75.0\% (in grains) in the $\mathrm{P}_{10,20,30,40}$ treatments as compared to $\mathrm{P}_{0.0}$ treatments. The phosphate may be limited solubility as well. Therefore, mobility and bioavailability of $\mathrm{Cd}$ in neutral to alkaline soils is low (McBride, 1994).

Table (3): Effect of different levels of phosphorus on heavy metals concentration (mg. $\left.\mathrm{kg}^{-1}\right)$ in shoot parts and the heavy metals uptake $\left(\mu \mathrm{g}\right.$. pot $\left.{ }^{-1}\right)$ by Wheat plant.

\begin{tabular}{|c|c|c|c|c|c|c|c|c|c|c|c|c|}
\hline \multirow[t]{2}{*}{$\begin{array}{l}\text { Part of } \\
\text { plant }\end{array}$} & \multirow[t]{2}{*}{$\begin{array}{c}\mathrm{mg} \mathrm{P} P \\
\mathrm{~kg}^{-1} \text { soil }\end{array}$} & $\mathrm{Fe}$ & $\mathrm{Ni}$ & $\mathrm{Cd}$ & $\mathrm{Pb}$ & $P$ & $\begin{array}{c}\text { Dry } \\
\text { Matter } \\
\text { Weight }\end{array}$ & $\mathrm{Fe}$ & $\mathrm{Ni}$ & $\mathrm{Cd}$ & $\mathrm{Pb}$ & $P$ \\
\hline & & \multicolumn{5}{|c|}{ Conc. (mgkg $\left.{ }^{-1}\right)$} & g.pot ${ }^{1}$ & \multicolumn{5}{|c|}{ Uptake ( $\mu$ g. pot $\left.{ }^{-1}\right)$} \\
\hline \multirow{6}{*}{ Shoot } & 0 & 31.70 & 0.130 & 0.010 & 0.183 & 0.350 & 15.60 & 494.52 & 2.028 & 0.156 & 2.85 & 5.46 \\
\hline & 10 & 39.45 & 0.115 & 0.002 & 0.148 & 0.360 & 16.04 & 632.77 & 1.845 & 0.032 & 2.37 & 5.77 \\
\hline & 20 & 41.00 & 0.105 & 0.0016 & 0.152 & 0.373 & 16.50 & 676.50 & 1.732 & 0.027 & 2.50 & 6.15 \\
\hline & 30 & 31.47 & 0.105 & 0.0011 & 0.116 & 0.389 & 16.98 & 534.36 & 1.782 & 0.019 & 1.97 & 6.60 \\
\hline & 40 & 30.52 & 0.090 & 0.0010 & 0.115 & 0.384 & 18.00 & 549.36 & 1.620 & 0.018 & 2.07 & 6.91 \\
\hline & $\mathrm{LSD}_{05}$ & 3.046 & 0.011 & 0.102 & 0.022 & 0.007 & 1.708 & 78.33 & 0.231 & 0.138 & 0.433 & 0.691 \\
\hline
\end{tabular}


Mesopotamia J. of Agric.

Vol. (42) NO. (1) 2014
ISSN: 2224-9796 (Online)

ISSN: $1815-316 \times$ (Print)

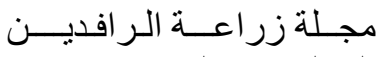

المجلد(42) العدد(1) 2014 2014

Table (4): Effect of different levels of phosphorus on heavy metals concentration $\left(\mathrm{mg} \cdot \mathrm{kg}^{-1}\right)$ in grain and the heavy metals uptake $\left(\mu \mathrm{g} \cdot \mathrm{pot}^{-1}\right)$ by Wheat plant.

\begin{tabular}{|c|c|c|c|c|c|c|c|c|c|c|c|c|}
\hline \multirow{2}{*}{$\begin{array}{c}\text { Part } \\
\text { of } \\
\text { plant }\end{array}$} & \multirow[t]{2}{*}{$\begin{array}{c}\mathrm{mg} P \\
\mathrm{~kg}^{-1} \text { soil }\end{array}$} & $\mathrm{Fe}$ & $\mathrm{Ni}$ & $\mathrm{Cd}$ & $\mathrm{Pb}$ & $P$ & \multirow{2}{*}{$\begin{array}{c}\text { Dry } \\
\text { Matter } \\
\text { Weight }\end{array}$} & $\mathrm{Fe}$ & $\mathrm{Ni}$ & $\mathrm{Cd}$ & $\mathrm{Pb}$ & $P$ \\
\hline & & \multicolumn{5}{|c|}{ Conc. (mgkg-1) } & & \multicolumn{5}{|c|}{ Uptake ( $\mu \mathrm{g} \cdot$ pot $\left.^{-1}\right)$} \\
\hline \multirow{6}{*}{ Grain } & 0 & 42.00 & 0.356 & 0.004 & 2.74 & 0.37 & 2.15 & 90.30 & 0.765 & 0.0086 & 5.891 & 0.79 \\
\hline & 10 & 41.59 & 0.383 & 0.001 & 2.55 & 0.46 & 2.29 & 95.24 & 0.877 & 0.0023 & 5.839 & 1.03 \\
\hline & 20 & 39.52 & 0.355 & 0.002 & 1.12 & 0.47 & 2.51 & 99.19 & 0.891 & 0.0050 & 2.811 & 1.15 \\
\hline & 30 & 39.50 & 0.354 & 0.001 & 0.94 & 0.47 & 2.91 & 115.00 & 1.030 & 0.0043 & 2.735 & 1.36 \\
\hline & 40 & 39.22 & 0.176 & 0.001 & 0.55 & 0.47 & 3.00 & 117.66 & 0.528 & 0.0029 & 1.650 & 1.41 \\
\hline & LSD. 05 & 4.239 & 0.038 & 0.011 & 0.36 & 0.055 & 0.852 & 34.72 & 0.296 & 0.024 & 1.53 & 0.435 \\
\hline
\end{tabular}

The application of $\mathrm{P}$ significantly reduced the concentration of $\mathrm{Pb}$ in the roots, shoots and grains of wheat plant. The $\mathrm{Pb}$ percent concentrations in the root decrease were $11.18,32.63,55.59$ and $75.23 \%$ in the $\mathrm{P}_{10,20,30,40}$ treatments as compared to $\mathrm{P}_{0}$ treatments respectively (Table 2).

For shoot $\mathrm{Pb}$ concentration the magnitude of reduction with an increase of $\mathrm{P}$ supply were $19.13,16.93,36.61$ and $37.16 \%$ in the $\mathrm{P}_{10,20,30,40}$ treatments as compared to $\mathrm{P}_{0}$ treatment (Table 3 ).

Grain $\mathrm{Pb}$ concentration percent decreases were 6.93, 59.12, 65.69 and $79.92 \%$ in the $\mathrm{P}_{10,20,30,40}$ treatments as compared to $\mathrm{P}_{0}$ treatments respectively (Table 4).Lead accumulated mainly in the root, and only small fraction of this $\mathrm{Pb}$ was transported to the shoots of wheat plant .Similar results were found by (Kabata - Pendias and Pendias, 1995)

$$
\begin{aligned}
& \text { تأثثر مستويات مختلفة من السماد الفوسفاتي على تركيز العنا صر الثقيلة في الأجزاء المختلفة لنبات }
\end{aligned}
$$

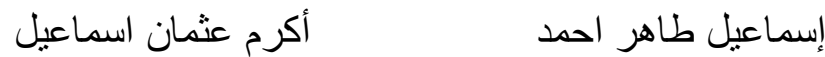

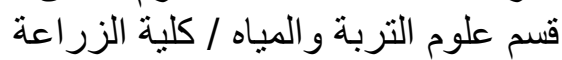

$$
\begin{aligned}
& \text { جامعة صلاح الدين } \\
& \text { ismaeelshexbzeny@yahoo.com }
\end{aligned}
$$

\footnotetext{
الخلاصة

اجريت التجربـة البايولوجيـة في 2011/1/20 الى 2011/6/2 في السئة السنادين في حقل التابعـة لكليـة 36²07 N, 4401E, 0411359, 03997002 UTM، الزر اعة الذي تقع 3.5 كم جنوب محافظه اربيل

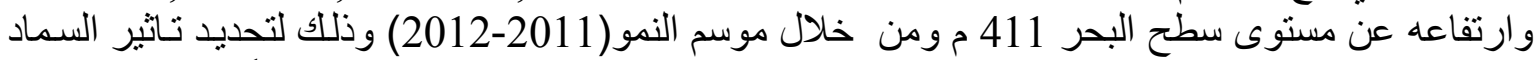
(سوبر فوسفات الثثلاثى ) وبمستويات مختلفه من الفسفور

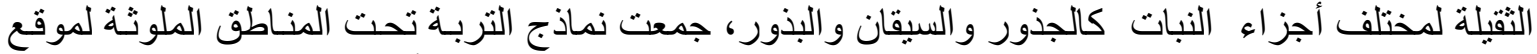

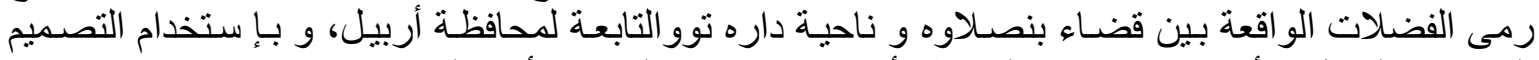

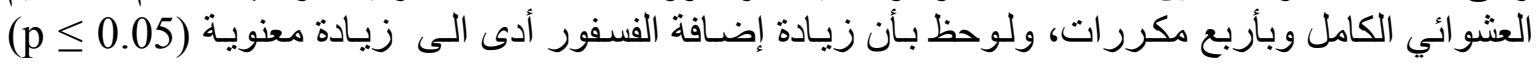




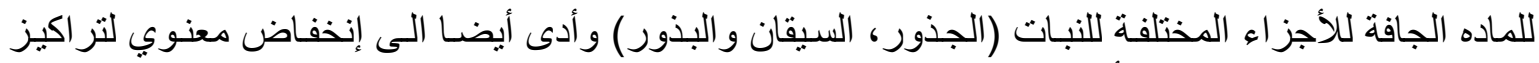

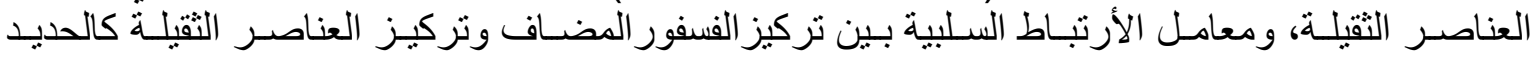

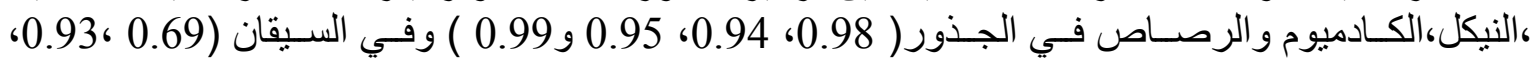

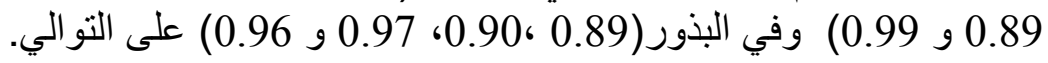

كلمات داله :الفسفور، العناصر التقيلة،الكمية الممتصة.

تاريخ تسلم البحث 2015 / 2012/10/15 وقبوله

\section{REFERENCES}

Adriano, D. (2001). Trace Elements In Terrestrial Environments: Biogeochemistry, Bioavailability and Risks of Metals, $2^{\text {nd }}$ edit. Springer, New York.

Allen, S. E. (1974). Chemical Analysis of Ecological Materials. Blackwell Scientific Publication Osney Mead, Oxford.

Anonymous (2005). Statistical Analysis System User Guide for personal computer .Version (9.1) Statistical Analysis Institute, Cary Inc., NC, USA.

Chaney, L. R.; S. B. Sterrett; H. W. Mielke (1984). The Potential for Heavy Metal Exposure from Urban Gardens and Soils USDA. Agriculture Resource Service. Biological Waste Management and Organic Resource Laboratory Study Beltsville, MD20705

Fageria, N. K. (2009). The Use of Nutrients in Crop Plants, $1^{\text {st }}$ edit. CRC Press Taylor and Francis Group, New York. pp 91-130.

Grant, CA.; LD. Bailey; MJ. McLaughlin; BR. Singh (1999). Management factors which influence cadmium concentration in crops. In 'Cadmium in Soils and Plants'. (Eds MJ McLaughlin, BR Singh) pp.151-198.(Kluwer Academic Publishers: Dordrecht).

Grant, CA.; LD Bailey; JT. Harapiak; NA. Flore (2002). Effect of phosphate source, rate and cadmium content and use of Penicillium bilaii on phosphorus, zinc and cadmium concentration in durum wheat grain. Journal of the Science of Food and Agriculture 82: 301-308.

Grant, CA, and SC. Sheppard, (2008). Fertilizer impacts on cadmium availability in agricultural soils and crops. Human and Ecological Risk Assessment 14: 210-228.

Hassan, N. A-K.; F. Aziz; E. Raban; S. Asker ; T. Al-Timimi (1975). Limits of phosphorus availability in representative Iraqi soils as measured by crop response and soil test values $.2^{\text {nd }}$ Scientific Conference, Baghdad, Iraq.

Havlin, J. L.; J. D. Beuton; S. L. Tisdale; W. L. Nelson (2007). Soil Fertility and Fertilizers, An Introduction To Nutrient Management, $7^{\text {th }}$ edit. p: 221 . Pearson Education Inc. Singapore.

Hseu, Z.Y.; Z.S. Chen; C.C. Tsai; C.C. Tsui; S.F. Cheng; C.L. Liu and H.T. Lin (2002). Digestion methods for total heavy metals in sediments and soils. Water Air Soil Pollution. 141: 189-205.

Kabata - Pendias, A.; H. Pendias (1995). Trace Elements in Soils and Plants, $2^{\text {nd }}$ edit. CRC press. Boca Raton USA

Kabata - Pendias, A.; H. Pendias (2001). Trace Elements In Soils and Plants, $4^{\text {th }}$ edit. CRC Press. Boca Raton USA.

McBride, M. B. (1994). Environmental Chemistry of Soils. Oxford University Press. Inc. New York.USA. 
Mekeague, J. A. (1978). Manual of Soil Sampling and Methods of Analysis. $2^{\text {nd }}$ edit. Consultant Society Soil Science. Ottawa. Ont.

Mengel, K.; E.A. Kirkby (2001). Principles of Plant Nutrition. $4^{\text {th }}$ edit. International Potash Institute. Bern. Switzerland.

Miretzky, P.; A. Fernandez-Cirelli (2010). Phosphate for Pb immobilization in soils: a review. Environmental Chemistry Letrature. Springer Verlag

Russell, E. J. (2001). Soil Conditions and Plant Growth. Published by Biotech Books. Printed at Chawla Offset Printers' .New Delhi.

Stewart, W.M.; A. Johnston; T. S. Murrel; R. L. Mikkelsen (2003). Phosphorus Nutrition of Wheat Optimizes Production Published by The Potash \& Potash Institutes (PPI) and potash institute of Canada (PPIC).

Taylor, MD. (1997). Accumulation of cadmium derived from fertilizers in New Zealand soils, Science of the Total Environment 208: 123-126.

Zhu, Y. G.; F. A. Smith; S. E. Smith (2002). Phosphorus efficiencies and their effects on $\mathrm{Zn}, \mathrm{Cu}$ and $\mathrm{Mn}$ nutrition of different barley (Hordeum vulgare) cultivars grown in sand culture, Australian Journal Agriculture Research. 53:211-21 